\section{References}

Dam, G. 1988: Sedimentological studies of the fluviatile shallow marine Upper Triassic to Lower Jurassic succession in Jameson Land, East Greenland. Rapp. Grønlands geol. Unders. 140, 76-79.

Hurst, J. M., Scholle, P. A. \& Stemmerik, L. 1989: Submarine cemented bryozoan mounds, Upper Permian, Devondal, East Greenland. Mem. Can. Soc. Petrol. Geol. 13.

Stemmerik, L. 1988: A preliminary study of the porosity and permeability of limestones and sandstones in the Jameson Land area, central East Greenland. Rapp. Grønlands geol. Unders. 140, 80-84.

Stemmerik, L., Scholle, P. A., Thomas, E., Amendolia, M., Henk, F. H. \& Uncini, G. 1989: Facies mapping and reservoir evaluation of the Upper Permian Wegener Halvø Formation in Wegener Halvø, East Greenland. Rapp. Grønlands geol. Unders. 145 (this volume).

Surlyk, F. 1983: Source rock sampling, stratigraphical and sedimentological studies in the Upper Palaeozoic of the Jameson Land basin, East Greenland. Rapp. Grønlands geol. Unders. $115,88-93$.
Surlyk, F., Callomon, J. H., Bromley, R. G. \& Birkelund, T. 1973: Stratigraphy of the Jurassic - Lower Cretaceous sediments of Jameson Land and Scoresby Land, East Greenland. Bull. Gronlands geol. Unders. 105, $76 \mathrm{pp}$.

Surlyk, F., Hurst, J. M., Piasecki, S., Rolle, F., Scholle, P. A., Stemmerik, L. \& Thomsen, E. 1986a: The Permian of the western margin of the Greenland Sea - a future exploration target. In Halbouty, M. T. (edit.) Future petroleum provinces of the world. Mem. Am. Ass. Petrol. Geol. 40, 629659.

Surlyk, F, Piasecki, S. \& Rolle, F. 1986b: Initiation of petroleum exploration in Jameson Land, East Greenland. Rapp. Grønlands geol. Unders. 128, 103-121.

\title{
Facies mapping and reservoir evaluation of the Upper Permian Wegener Halvø Formation in Wegener Halvø, East Greenland
}

\author{
Lars Stemmerik, Peter A. Scholle, Elizabeth Thomas, \\ Massimo Amendolia, F. H. Henk and Giuseppe Uncini
}

Field work was carried out from 17 July to 3 August by a joint group from ARCO, AGIP and GGU to evaluate the reservoir potential of the Upper Permian limestones in Wegener Halvø (fig. 1). The group was based south of Paradigmabjerg (fig. 1) and had a Bell 206 helicopter available full-time during the entire period. Logistic support was provided by the ARCO base at Constable Pynt.

The Upper Permian limestones in the Wegener Halv $\varnothing$ area have been investigated previously by GGU (Stemmerik, 1979; Surlyk, 1983; Surlyk et al., 1984a,b, 1986a; Hurst et al., 1989). Diagenetic studies of the limestones (Scholle, 1986; Hurst et al., 1989) indicate that reservoir properties are expected mainly to occur in the bryozoan-cement mounds of the Wegener Halv $\emptyset$ Formation. Accordingly, the 1988 programme concentrated on more detailed studies of these mounds and included a shallow drilling programme conducted by GGU (see Christiansen \& Stemmerik, 1989).

\section{Facies mapping}

The facies mapping of the Wegener Halvø Formation involved both detailed mapping of individual mound complexes and mapping of the regional distribution of mounds. The overall facies distribution and thickness variation is well delineated by Surlyk et al. (1986a) and Hurst et al. (1989). The present study confirmed the overall thinning of the formation to the west, although local variations make the pattern more complex than previously indicated. This is particularly the case along the east coast of the peninsula where the location of the larger mounds was found to be controlled by the topography of the karst surface of the underlying Karstryggen Formation.

The mounds have a complex depositional history and include a variety of shallow marine to deeper water facies. In addition to these facies recorded by Surlyk $e t$ al. (1986a) and Hurst et al. (1989), a volumetrically important facies composed of calcite pseudomorphs after botryoidal aragonite with a few volume percent bryozoans was found (fig. 2). This facies represents the core of the largest mounds in the area and is accordingly restricted to the eastern part of the peninsula (fig. 1).

Four different types of mound were tentatively distinguished on the basis of facies distribution and types of post-mound events. 


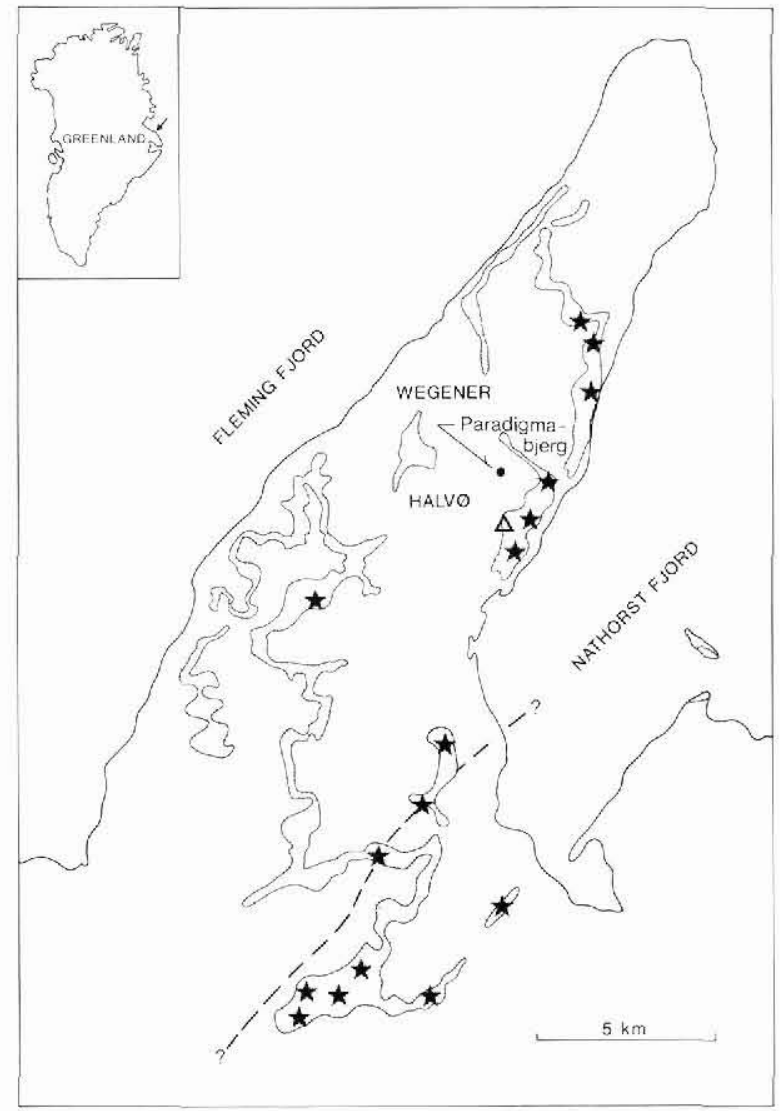

Fig. 1. Map of Wegener Halvø showing the Upper Permian outcrops, location of field camp (triangle) and location of major build-ups (types 3 and 4 ). The dotted line marks the northwestern limit of type 4 mounds.

(1) Stromatolite-bivalve mounds are composed of stromatolitic limestone and bivalve packstone to grainstone. This type is widely distributed throughout the region, forming small isolated mounds (less than $10 \mathrm{~m}$ high, $50-100 \mathrm{~m}$ wide) to the west (fig. 3) and the basal part of larger mounds to the east.

(2) Bryozoan mounds represent an intermediate form of mound development where stromatolite-bivalve mounds are overlain by bryozoan packstones and grainstones. These mounds are less than $20 \mathrm{~m}$ high and are not surrounded by mound debris deposits. This type is widely distributed in the western half of the region (fig. 2).

(3) Bryozoan-cement mounds. This type of mound consists of a thick sequence of bryozoan-submarine cementstone which forms on top of the above-mentioned facies (types 1 and 2). These complex core facies are sur-

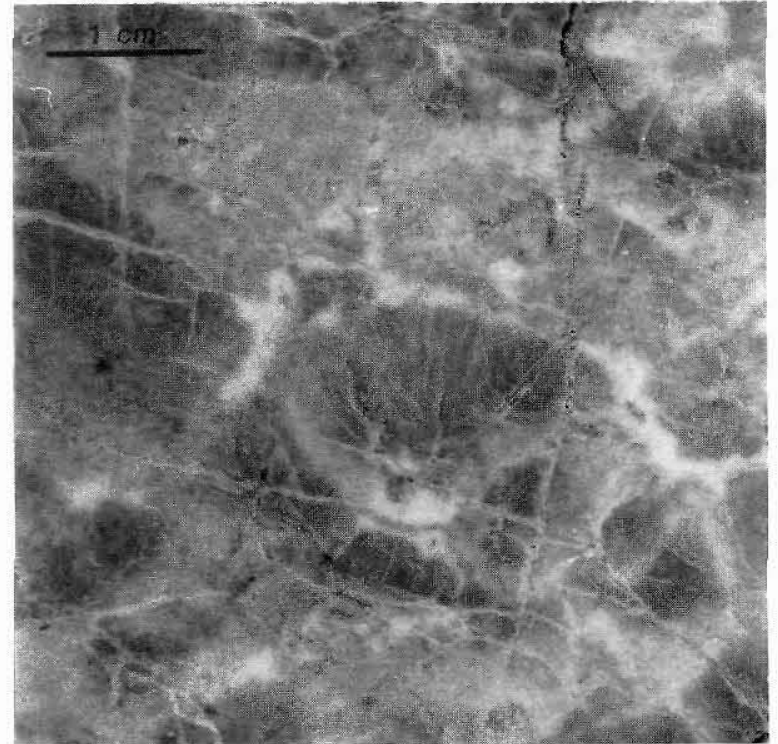

Fig. 2. Submarine aragonite fan, now preserved as calcite. Core facies of types 3 and 4 mounds.

rounded by steeply dipping mound debris beds which form most of the mound volume. Typically, the core facies proper is $50-150 \mathrm{~m}$ across and less than $70 \mathrm{~m}$ thick. This type of mound is found as isolated features in the northeastern part of Wegener Halvø (figs 1, 4) located on top of karst highs.

These 3 types of mound are all capped by shales of the Ravnefjeld Formation and are therefore suggested to represent deposition during continuous deepening of the water. This is in contrast to the last type of mound recognized in the area.

(4) Bryozoan-cement mounds capped by oolite shoals. These mounds are distinguished from type 3 mounds by having a capping sequence of shallow water limestone which locally shows evidence of subaerial exposure. The mounds are directly overlain by sandstones of the Schuchert Dal Formation or by Triassic sediments. It is evident that these mounds formed topographic highs in the latest Permian and earliest Triassic times and that they were occasionally subjected to erosion. This type is confined to the southeastern part of the area (fig. 1).

From a reservoir point of view, only types 3 and 4 mounds are sufficiently large to be of some interest. Reservoir potential of these mounds appears largely related to the flanking deposits (Hurst et al., 1989). Although porous intervals in the mound cores have been found to contain bitumen, the cores appear too densely cemented to be of interest as reservoirs. The size of the individual mounds is not large enough to 


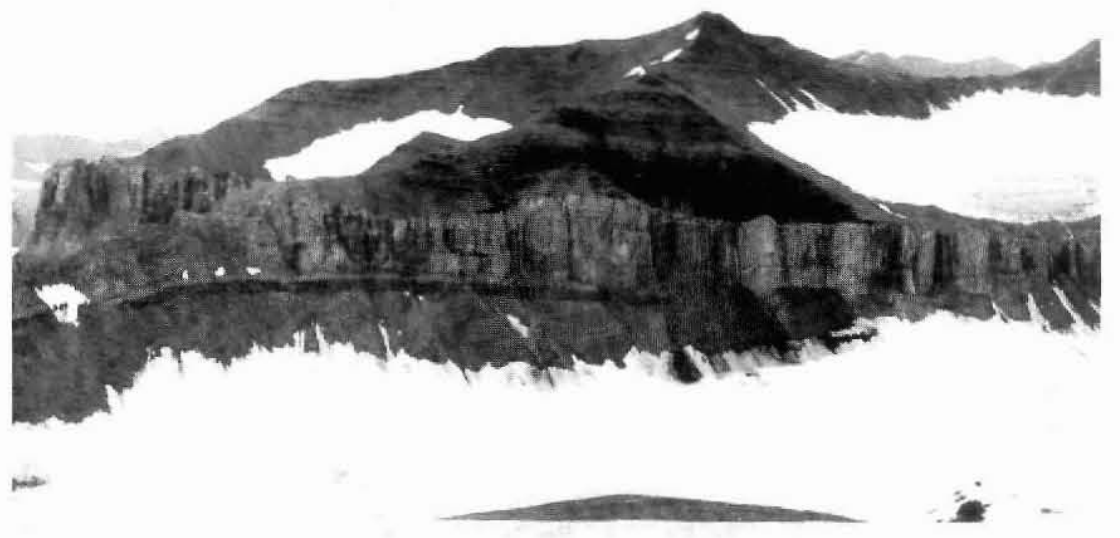

Fig. 3. Stromatolite-bivalve (type 1) and small bryozoan (type 2) mounds in the western part of Wegener Halvø.

allow commercial production. In the southeastern part of Wegener Halvø, however, the mounds apparently merge and form large atoll-like mound complexes. The reservoir potential of the Wegener Halvø Formation therefore depends on the occurrence and size of comparable atoll-like mound complexes in the subsurface.

\section{Bitumen occurrences}

Bitumen was found to be widespread in the Wegener Halvø Formation (fig. 5). In the western part bitumen occurs associated with type 1 mounds while elsewhere it is confined to porous zones in the cores of types 3 and 4 mounds (fig. 6). The discovery of bitumen in this setting demonstrates the validity of an Upper Permian limestone reservoir with Ravnefjeld Formation shales as both source rock and cap rock (e.g. Surlyk et al., 1986a,b).

Acknowledgements. GGU's participation in the field programme was financially supported by the Mineral Resources Administration for Greenland.

\section{References}

Christiansen, F. G. \& Stemmerik, L. 1989: Shallow core drilling of Upper Permian and Upper Triassic - Lower Jurassic
Fig. 4. Core of type 3 mound located on top of karst limestones of the Karstryggen Formation.

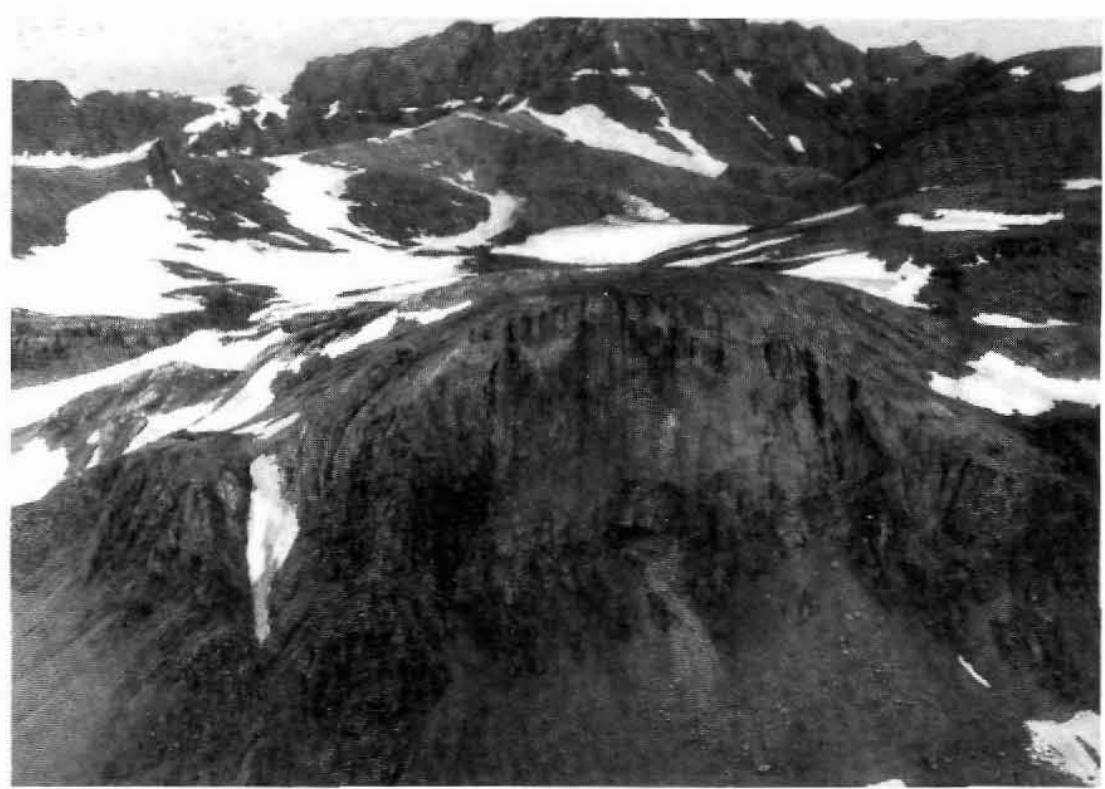




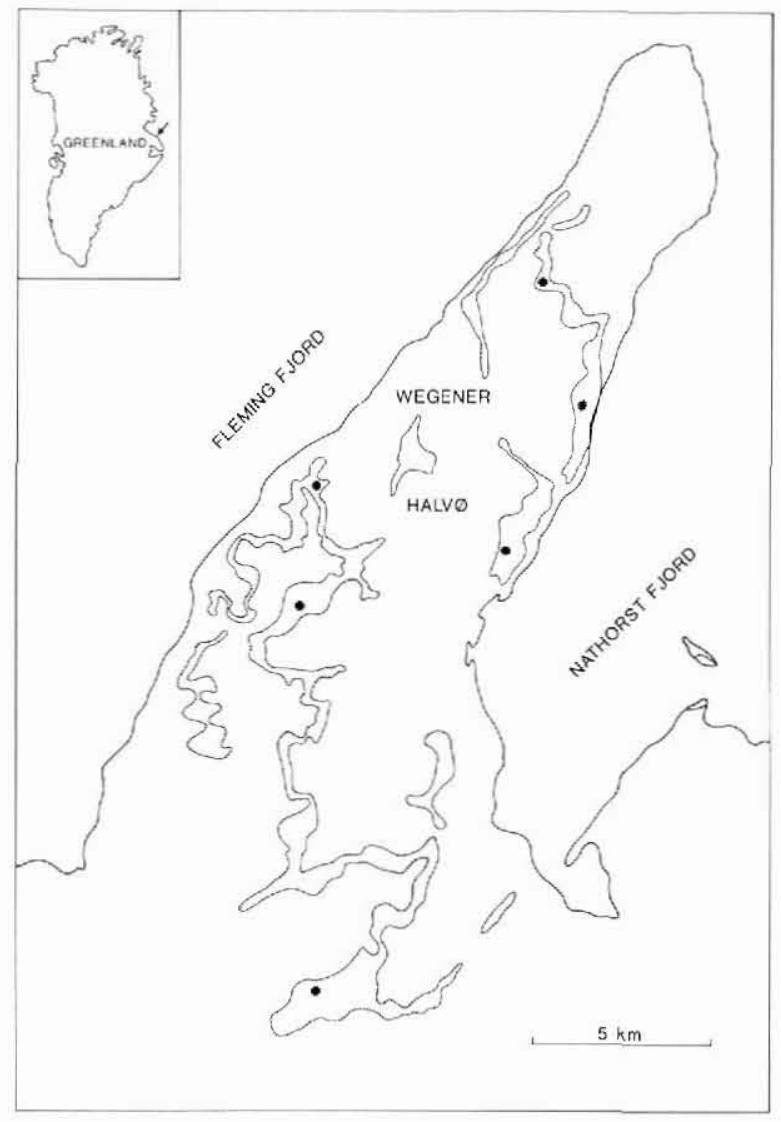

Fig. 5. Map of Wegener Halvø showing Upper Permian outcrops and location of bitumen found within the Wegener Halvø Formation.

potential reservoir rocks in central East Greenland. Rapp. Gronlands geol. Unders. 145 (this volume).

Hurst, J. M., Scholle, P. A. \& Stemmerik, L. 1989: Submarine cemented bryozoan mounds, Upper Permian, Devondal, East Greenland. Mem. Can. Soc. Petrol. Geol. 13.

Scholle, P. A. 1986: Diagenetic history and petroleum potential of Permian carbonate buildups, central East Greenland. 12th Int. Sedimentology Congr. (Canberra) Abstracts, 271 only.

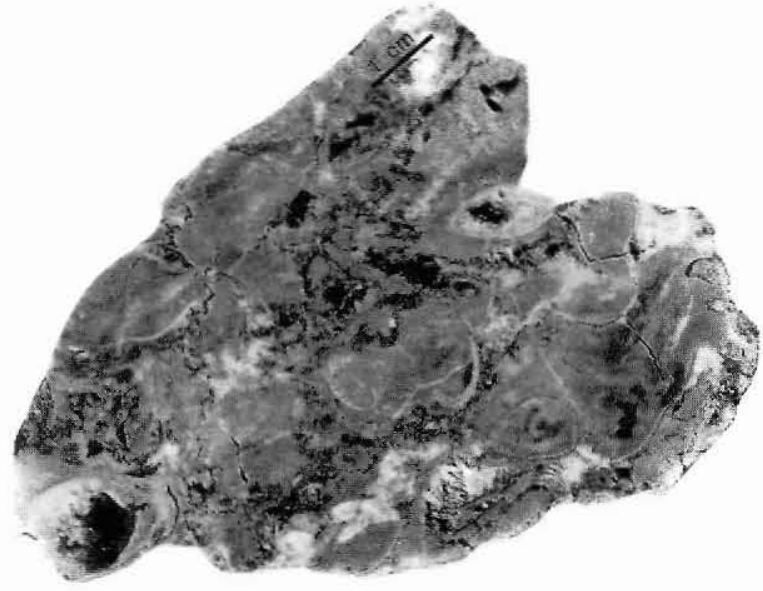

Fig. 6. Bitumen in non-cemented part of mound core.

Stemmerik, L. 1979: Observations on the Upper Permian of Wegener Halvø, East Greenland. Rapp. Grønlands geol. Unders. 95, 90-92.

Surlyk, F. 1983: Source rock sampling, stratigraphical and sedimentological studies in the Upper Palaeozoic of the Jameson Land basin, East Greenland. Rapp. Gronlands geol. Unders. $115,88-93$.

Surlyk, F., Hurst, J. M., Marcussen, C., Piasecki, S., Rolle, F., Scholle, P. A., Stemmerik, L. \& Thomsen, E. 1984a: Oil geological studies in the Jameson Land basin, East Greenland. Rapp. Gronlands geol. Unders. 120, 85-90.

Surlyk, F., Piasecki, S., Rolle, F., Stemmerik, L., Thomsen, E. \& Wrang. P. 1984b: The Permian basin of East Greenland. In Spencer, A. M. et al. (edit.) Petroleum geology of the North European margin, 305-315. London: Graham \& Trotman.

Surlyk, F., Hurst, J. M., Piasecki, S., Rolle, F., Scholle, P. A., Stemmerik, L. \& Thomsen, E. 1986a: The Permian of the western margin of the Greenland Sea - a future exploration target. In Halbouty, M. T. (edit.) Future petroleum provinces of the world. Mem. Am. Ass. Petrol. Geol. 40, 629-659.

Surlyk, F., Piasecki, S. \& Rolle, R. 1986b: Initiation of petroleum exploration in Jameson Land, East Greenland. Rapp. Gronlands geol. Unders. 128, 103-121.
P.A.S.

Dept of Geological Sciences.

Southern Methodist University,

Dallas, Texas 75275 ,

U.S.A.
$M, A \& G, U$ AGII.

PO. Box 12069

20120 Milano, Iraiy.
E.T\&EH.H. ARCO International, 444 South Flower Street, Los Angeles, California, 90017 .

L. S.

Gronlands Geologiske Undersogelse,

Oster Voldgade 10.

$D K-1350$ Kobenhavn $K$

Danmark. 